\title{
Community Empowerment Strategies in Alleviating Poverty during Covid-19 Pandemic
}

\author{
Diryo Suparto ${ }^{1}$, Rahmad Agung Nugraha ${ }^{2}$ \\ Universitas Pancasakti Tegal Indonesia ${ }^{1,2}$ \\ \{suparto.diryo@gmail.com ${ }^{1}$ \}
}

\begin{abstract}
The purpose of this research is to find out the strategies carried out by community empowerment agencies in the context of poverty alleviation and what obstacles are faced and how to solve problems in poverty alleviation during the Covid 19 Pandemic. In this research using a qualitative research approach, focusing on the strategies undertaken.

This study uses qualitative research with a descriptive research design model, namely research conducted by giving an in-depth description and explanation of an object and aims to describe, summarize various conditions, various situations or various social reality phenomena that exist in the community which are the object of research. with surface reality as a feature, character, nature, model, sign or description of a condition, situation or phenomenon.

The results showed that there are several things that need attention, namely, First, related to the social safety net program through the assistance scheme, both assistance in the form of foodstuffs, subsidies, and direct cash assistance. It is no secret that the fundamental problem of this assistance is data accuracy, so that the aid is not on target. The government needs to evaluate the implementation of Presidential Regulation Number 39 of 2019 concerning One Indonesian Data. Second, making decisions based on evidence (evidence based policy) is a necessity, especially in determining the priority and target of intervention. Comprehensive research can produce quality and applicable policies. Grounding research-based policies is still a challenge in Indonesia. Research-based policy making opens the tap of participation and collaboration of researchers to contribute to policy making. Third, strengthen the role of the National Team for the Acceleration of Poverty Reduction, especially in coordinating across sectors and across stakeholders, including the availability of integrated data and the results of poverty reduction research. So far this function has not been running well, the impact is that poverty reduction programs are not running effectively. Community empowerment strategies to develop community economic productivity, which must be adjusted to the potential of the community and the resource environment. Develop community business products, develop the agricultural sector, develop the fishery sector, manage the marketing sector.
\end{abstract}

Keywords: Community Empowerment Strategy, Poverty Alleviation, Covid-19 Pandemic 


\section{Introduction}

Poverty is a problem in development characterized by unemployment and underdevelopment, which then escalates to inequality. Poverty and low human resources present obstacles. People's economic development is a poverty alleviation movement that invites the widest possible participation of the community and all parties. The population takes the role of the subject in every effort to reduce poverty. Because they are the ones who know best about the problems faced in the socio-economic field. Community empowerment is an effort to make the community independent through the realization of their abilities.

The concept of community empowerment using a people-centered development paradigm. In this approach, every development effort needs to be directed and created an environment that is much better and at the same time widens the choice of employment-business for each member of society. Empowerment refers to the ability of people. Especially vulnerable and weak groups so that they have the strength or ability to fulfill their basic needs so that they have freedom, in the sense of not only being free to express opinions, but free from hunger, free from ignorance, free from pain, reaching productive sources enabling them to increase their income and obtain the goods and services they need to participate in the development process and the decisions that affect them (Sugiarto, 2005).

Furthermore, Sugiarto (2005) states that empowerment is a series of activities to strengthen the strength or empowerment of vulnerable and weak groups in society, including individuals who experience poverty problems, so that they have the empowerment to meet their daily needs both physically, economically and socially such as : self-confidence, as well as conveying aspirations, having a livelihood, participating in social activities and being independent in carrying out life tasks. The method used in empowering is by providing motivation or support in the form of resources, opportunities, knowledge, and skills for the community to increase their capacity, increase awareness of their potential, then try to develop their potential. Another definition of empowerment is put forward by Rukminto (2002) which states that the notion of empowerment basically discusses how individuals, groups or communities try to control their own lives and seek to shape the future according to their wishes. This understanding is in accordance with the opinion of Biestek which is known in the field of Social Welfare Education under the name "Self-Determination". This principle essentially encourages clients to determine for themselves what they should do in relation to efforts to overcome the problems they face, so that clients have full awareness and power in shaping their future.

Thus, the meaning of empowerment is not only one interpretation, but it can have multiple interpretations, where one interpretation is not necessarily the same. Even so, the targets and goals of empowerment itself may differ according to the development sector being worked on (Rukminto, 2002).

The efforts to reduce the degree of poverty that have been carried out so far are still very vulnerable to changes in economic, political, social conditions that have occurred especially coupled with the conditions of this Covid pandemic. This shows that there are still some weaknesses in poverty reduction in the past that need fundamental correction. In this regard, it is mandatory for all components of society to reinforce attitudes towards the problem of poverty during the Covid pandemic, both from economic, social, political and moral reasons, so it is necessary to formulate an appropriate and sustainable poverty reduction strategy through community empowerment strategies, so that efforts are made to poverty alleviation was successful. 


\section{Literature Review}

At first the development efforts of developing countries were identified with efforts to increase per capita income, or what is popularly called the economic growth strategy. Initially, many thought that what distinguished developed countries and NSB was the income of their people. With the increase in per capita income, it is hoped that problems such as unemployment, poverty and inequality in income distribution faced by NSB can be resolved, for example through what is known as the "trickle down effect". The indicator of success or failure of development is solely seen from the increase in real national income (GNP) per capita, in the sense that the growth rate of national income in constant prices (after being deflated by the price index) must be higher than the rate of population growth. Redefinition of economic development is manifested in an effort to eliminate, at least reduce, poverty, unemployment and inequality. Kuncoro (2003) pointed to three main development goals by saying:

“... What has been happening to poverty? What has been happening to unemployment? What has been to inequality? If all three of these have declined from high levels then beyond doubt this has been a period of development for the country concerned. If one or two these central problems have been growing worse, especially if all three have it would be strange to call the result 'development', even if per capita income doubled".

The definition above is a redefinition of development in the context of social goals. This obsession seems to be driven by his concern over the realities of development regarding antipoverty strategies, orientation to job opportunities, and equitable development, which often stop only as political rhetoric of the rulers.

The current development paradigm has shifted towards community development with a strategy of community empowerment and participation. Prijono and Vidyandika (1996) explain that empowerment is an increase in people's independence based on the people's internal capacity and strength over human resources, both material and non-material, through capital redistribution. Korten's empowerment paradigm assumes that development will run automatically if people are given the right and freedom to participate in managing their natural resources and using them for community development.

Kartasasmita (1996), empowerment is defined as strength that comes from within, which can be strengthened by elements from outside. Empowerment is an effort to build that power, by encouraging, motivating and raising awareness of its potential and trying to develop it.

Payne (1997) argues that an empowerment is basically aimed at:

"To help clients gain power of decision and action over their own lives by reducing the effects of social or personal blocks to exercising existing power, by increasing capacity and self-confidence to use power and by transferring power from the environment to clients"

Rukminto (2002) states that the notion of empowerment essentially discusses how individuals, groups or communities try to control their own lives and seek to shape the future according to their wishes. This understanding is in accordance with the opinion of Biestek which is known in the field of Social Welfare Education under the name "Self-Determination". This principle essentially encourages clients to determine for themselves what they should do in relation to efforts to overcome the problems they face, so that clients have full awareness and power in shaping their future.

Thus, the meaning of empowerment is not only one interpretation, but it can have multiple interpretations, where one interpretation is not necessarily the same. Even so, the targets and goals of empowerment itself can differ according to the development sector being worked on (Rukminto, 2002: 163). Poverty and inequality are development problems faced by every 
country, both in developing countries and in developed countries. Poverty is related to various factors, for example: income, health, education, access to goods and services, location, geography, gender and environmental conditions.

Poverty according to Kuncoro (2003) defines as the inability to meet the minimum standard of living. Meanwhile, Soerjono (2002) argues that poverty is defined as a condition in which a person is unable to maintain himself according to the standard of life of the group and is also unable to utilize mental and physical energy in the group. Then the definition of poverty according to the World Conference for Social Development (World Summit for Social Development) is as follows:

Poverty has multiple forms, including low levels of income and productive resources that ensure sustainable life; hunger and malnutrition; low level of health; limitations and lack of access to education and other basic services; growing morbidity and mortality from disease; homeless life and inadequate housing; unsafe environment; and social discrimination and alienation. Poverty is also characterized by low levels of participation in decision-making processes and in civil, social and cultural life. Based on the complexity and diversity of the dimensions of poverty, the causes of poverty in one region and another can be very different, even at the household and individual level, so that in an effort to find out the roots of poverty, it must be seen according to each characteristic.

Poverty is a complex problem and is influenced by various interrelated factors. Therefore, to alleviate poverty, cannot be separated from the demand for stability in the economic, social and political fields. Stability in all of these fields is a necessary condition for creating a conducive macro climate for efforts to reduce poverty. Furthermore, equitable economic growth is needed to reduce poverty. This relationship can simply be described as the causes of poverty from an economic perspective. First, on a micro level, poverty arises because of the unequal patterns of resource ownership which result in an unequal income distribution. The poor have only limited and low quality resources. Second, poverty arises from differences in the quality of human resources. Low quality human resources means low productivity, which in turn low wages. The low quality of human resources is due to low education, unfortunate fate, discrimination, or heredity. Third, poverty arises from differences in access to capital.

The three causes of poverty boil down to the vicious circle of poverty theory. The existence of underdevelopment, market imperfections and lack of capital lead to low productivity. Their low productivity results in the low income they receive. Low income will imply low savings and investment. Low investment results in underdevelopment, and so on. This logic of thinking was put forward by Ragnar Nurkse, a well-known development economist, in 1953, who said: "a poor country is poor because it is poor" (a poor country is poor because he is poor).

The management of economic development has a tendency to lack capital followed by low productivity, decreased real income, low savings and investment has decreased so that it looped back to a state of lack of capital and so on spinning. Therefore, every effort to fight poverty should be directed to cut this poverty circle and trap. Based on the complexity of the poverty problem, efforts to overcome it need to be carried out in a comprehensive and integrated manner by involving development actors (government, private and community). The main points that need to be considered in poverty reduction in a comprehensive and integrated manner include:

a. The problem of poverty needs to be seen as a multidimensional symptom involving economic, social and cultural, legal and political aspects, as well as defense and security, so that overcoming it requires a comprehensive poverty reduction strategy. 
b. There is a need for mainstreaming, starting from strategy, macro policies to operational micro policies, as well as synchronization between policies and programs as a measure to streamline poverty reduction efforts.

c. The poverty reduction process is just as important, or even more important than the end result. One important element of the poverty reduction process is the level of participation of various development actors (government, private and community), starting from the formulation of policies and programs, implementing policies and programs to monitoring and evaluation.

d. A good strategy and planning will be meaningless if it is not supported by good working methods from the institutions involved in implementing policies and programs, especially by the government, so that the implementation of policies and programs must be free from irregularities and leakages. Improving the way of working and creating greater opportunities for the poor to participate are two important steps to empower the poor.

Naturally, the development process must emerge from the community, be carried out by the community, and the results can be enjoyed by the community, while the government acts as a catalyst and controller of development. The Central Statistics Agency has released data on poverty conditions in March 2020 of 9.78 percent. This figure increased by 0.56 percentage points compared to the conditions in September 2019. The number of poor people in March 2020 reached 26.42 million people, an increase of 1.63 million people from the conditions in September 2019.

This condition is certainly not what the government wants, considering that over the last few years the budget disbursed for poverty alleviation programs has been enormous. In fact, it is suspected that the poor will continue to increase if the Covid-19 pandemic cannot be controlled by the government. As is known, due to the pandemic, massive layoffs (layoffs) occurred, many employees were laid off, income was drastically reduced, even income was nonexistent. Last month BPS also released the condition of Indonesia's employment conditions in February 2020. Although there has been no major decline by February 2020, the signs are already visible that many people will lose their jobs. Unemployment increased by 60 thousand people and has the potential to continue to experience a large increase.

People who work in the informal sector reach 56.50 percent or 74.04 million people. This sector is very prone to job loss or at least a drastic reduction in income. Nearly poor people who work in the informal sector in March 2020 reached 12.15 million. It is most likely that this group is the biggest contributor to the increase in poverty. Currently, their fall into poverty is happening and will probably continue to increase in the future.

\section{Research Method}

This study uses qualitative research with a descriptive research design model, namely research carried out by giving an in-depth description and explanation of an object and aims to describe, summarize various conditions, various situations or various social reality phenomena that exist in the community which are the object of research. with surface reality as a feature, character, nature, model, sign or description of a condition, situation or phenomenon. This research is one way to know and measure both in terms of the consequences of a program as well as the revisions that need to be made during program preparation, implementation and continuation of a program in the future. In implementation, the researcher conducts a survey, with the intention of knowing the object and determining the similarity of status by comparing it with the standards that have been selected or determined (Sensing, 2011). Researchers try to 
find answers to the phenomena of the problems posed and then describe them, so that they will get a meaningful picture of knowing the strategies carried out by community empowerment agencies in Local Government in the context of poverty alleviation and what obstacles are faced and how to solve problems in poverty alleviation in The Pandemic Covid 19.

The qualitative method referred to in this study is a taxonomic analysis of the problem of poverty alleviation. The steps taken were organizing the collected data consisting of notes, comments and field informants, documents in the form of article reports and so on. The analysis was carried out throughout the study and was carried out continuously from the beginning to the end of the study. Data analysis in this study used an approach through data reduction procedures, data presentation and data verification. The three processes are carried out together, as long as the research is carried out.

\section{Research Results}

Covid-19 pandemic situation To increase economic stability, sharp economic growth where economic growth is minus 5 percent which contributes to poverty. Based on data from the Central Statistics Agency, the number of poor people in Indonesia in March 2020 was 26.42 million people, consisting of poverty in urban areas of 11.16 million people or 7.38 percent and 15.26 million people in rural areas or 12.82 percent. . The urban poverty rate increased by 1.3 million people from 9.86 million people in September 2019 to 11.16 million people in March 2020. Meanwhile, the poverty rate in rural areas increased by 333.9 million people from 14.93 million people in September 2019 to 15.26 million people as of March 2020.

The Indonesian Poverty Line is IDR 454,652 per capita per month with an average poor household having 4.66 household members, meaning that the average poverty line in Indonesia is IDR 2,118,678 / poor household / month. The slow increase in the poverty rate in rural areas does not look at the occupation sector of the population, namely agriculture. Where agriculture is one of the sectors that is not significantly affected by the pandemic compared to industry and Micro, Small and Medium Enterprises. Meanwhile, urban communities, on average, work in industry and MSMEs, which are hit by the pandemic, have an impact on waves of layoffs (PHK).

The Indonesian government has provided a stimulus to people affected by the pandemic, if you look at the facts, the poverty data does not rule out the possibility that by the end of 2020 the poverty rate will rise higher in the range of 0.5-2 percent. Moreover, the impact of the pandemic will correct economic growth even more sharply. The government's strategy in maintaining economic stability by providing a stimulus to the public has not been fully effective. There are several things that need attention, namely:

a. First, related to the social safety net program through assistance schemes, either in the form of foodstuffs, subsidies or direct cash assistance. It is no secret that the fundamental problem of this assistance is data accuracy, so that the aid is not on target. The government needs to evaluate the implementation of Presidential Regulation Number 39 of 2019 concerning One Indonesian Data.

b. Second, making decisions based on evidence (evidence based policy) becomes a necessity, especially in determining the priority and target of intervention. Comprehensive research can produce quality and applicable policies. Grounding research-based policies is still a challenge in Indonesia. Research-based policy making opens the tap of participation and collaboration of researchers to contribute to policy making. Keynes stated that there is 
nothing a government hates more than complete and detailed knowledge, because it makes the process of getting to decisions much more complex and difficult.

c. Third, strengthen the role of the National Team for the Acceleration of Poverty Reduction, especially in coordinating across sectors and across stakeholders, including the availability of integrated data and results of poverty reduction research. So far this function has not been running well, the impact is that poverty reduction programs are not running effectively.

The Covid-19 pandemic will be a serious challenge for efforts to reduce poverty in Indonesia. If the policy is wrong, it is not a reduction in the poverty rate but an increase in the poverty rate. Synergy and collaboration must be carried out and no less important to improve poverty data in order to create accurate and credible data.

Covid-19 can reduce the level of welfare of rural communities, families of SME actors and workers, and workers with low salaries in large and medium-scale enterprises to a lower level, even below the poverty line. Many near-poor families have fallen into poverty, and are very poor, as a result of the impact of Covid-19 on small-micro business operations, and workers who were laid off in various sectors of the formal and informal economy. Informal worker communities that depend on their daily income, such as public transportation drivers, motorcycle taxi drivers, parking attendants, people with disabilities, laid-off employees, school canteen traders, street vendors, and porters. For this reason, there is a need for village innovation in village development efforts through community empowerment strategies.

Strategy is a way to mobilize manpower, funds, power, and equipment to achieve the stated goals. The meaning of community empowerment itself is a process that develops and strengthens the community's ability to continue to be involved in a development process that takes place dynamically so that the community can solve the problems faced and can make decisions freely (independently) and independently.

The process of community empowerment has the starting point of making the community independent so that they can improve their own standard of living by using and accessing local resources as best as possible. The main target of community empowerment is the poor. In the process, it should be noted that women will be actively involved. The community empowerment process is accompanied by a team of facilitators who are multidisciplinary in nature. The community empowerment team should consist of men and women. The main role of the community empowerment team is to assist the community in carrying out the empowerment process. The role of the community empowerment team at the beginning of the process is very active but will diminish during the process until the community is able to continue their activities independently. Community empowerment is carried out through several stages as follows:

a. The first stage: Site Selection. The area selection was carried out in accordance with the criteria agreed upon by the institution, related parties and the community. The determination of these criteria is important so that the objectives of the institution in community empowerment will be achieved and the location selection is carried out very well.

b. Second stage: Socialization of Community Empowerment. Socialization of community empowerment is an activity that is very important to create communication and dialogue with the community. Socialization of community empowerment in the community helps to increase understanding of the community and related parties about the program. The socialization process greatly determines the community's interest in taking part and being involved in the program. 
c. Third stage: Community Empowerment Process. This stage consists of the following activities: 1). participatory study of the state of society, 2). group development, 3). preparation of plans and implementation of activities, as well as, and 4). participatory monitoring and evaluation.

d. Fourth stage: Community Independence. The process of community empowerment is a continuous learning process for the community with the aim of community independence in efforts to improve their standard of living. This means that the role of the community empowerment team will slowly be reduced and eventually stop. The role of the group empowerment team as facilitator will be fulfilled by group administrators or other parties deemed capable by the community. The time required for the implementation of community empowerment is uncertain. Community empowerment is a process that will run continuously.

Regarding community empowerment in the Regulation of the Minister of Villages, Development of Disadvantaged Areas, and Transmigration number 11 of 2019, it explains that cash for work is an activity to empower rural communities, especially the poor and marginalized which are productive by prioritizing the use of resources, labor, and local technology to provide additional wages / income, increase purchasing power, reduce poverty, and simultaneously support a reduction in stunting. With the cash-intensive scheme, the implementation of the Village Fund is expected to absorb a large number of workers, by providing direct cash honoraria (wages) to the workers involved, both daily and weekly, so as to strengthen people's purchasing power, increase economic growth, and public welfare, especially during the Covid-19 pandemic, which is still ongoing today. Community empowerment strategies to develop village economic productivity, which must be adjusted to the potential of the community and the village's resource environment.

a. Develop community business products. With natural resources and human resources that have not been managed in the village to be developed as products of productive community businesses, the way to focus on local commodities, for example, weaving skills, can create jobs. Sewing training, for example, can focus on current needs such as making cloth masks that can be of sale value during this pandemic. Or the community can make processed specialties or snacks that can be sold. The products of this business can be sold through SMEs, nearby stalls / shops, or online so that their reach is even wider.

b. Developing the agricultural sector. By providing modern technology facilities / assistance and superior seeds / fertilizers as well as bactericidal assistance so that they can produce fast and good harvests for the village community. The community farming movement needs to be encouraged, where people can use their house yards or their fields to be planted with vegetables or fruit plants that can be used as food investment for some time to come, people can plant any food plants and hope that they can exchange crops as an effort to build mutual welfare.

c. Developing the fisheries sector. Village communities can be taught to cultivate fish, which later can be consumed by themselves or sold and become a source of income. The house yard or empty land can be an opportunity to build a fish pond, of course, it requires direct training or through a fish cultivation guide book.

d. Manage the marketing sector. The community can be trained to use technology for selling and promotion via online media so that marketing is more widespread, access to transportation also needs to be facilitated in the village so that distribution runs smoothly so that the economy runs smoothly and increases. 


\section{Conclusion}

The results showed that there are several things that need attention. First, related to the social safety net program through the assistance scheme, both assistance in the form of foodstuffs, subsidies, and direct cash assistance. It is no secret that the fundamental problem of this assistance is data accuracy, so that the aid is not on target. The government needs to evaluate the implementation of Presidential Regulation Number 39 of 2019 concerning One Indonesian Data.

Second, making decisions based on evidence (evidence based policy) is a necessity, especially in determining the priority and target of intervention. Comprehensive research can produce quality and applicable policies. Grounding research-based policies is still a challenge in Indonesia. Research-based policy making opens the tap of participation and collaboration of researchers to contribute to policy making. There is nothing that a government hates more than complete and detailed knowledge, because it makes the process of getting to decisions much more complex and difficult. Third, strengthen the role of the National Team for the Acceleration of Poverty Reduction, especially in coordinating across sectors and across stakeholders, including the availability of integrated data and the results of poverty reduction research. So far this function has not been running well, the impact is that poverty reduction programs are not running effectively.

Community empowerment strategies to develop community economic productivity must be adjusted to the potential of the community and the community's resource environment. Developing community business products With natural resources and human resources that have not been managed in the village to be developed as productive community business products, the way to focus on local commodities, for example, weaving skills, can create jobs. Sewing training, for example, can focus on current needs such as making cloth masks that can be of sale value during this pandemic. Or the community can make processed specialties or snacks that can be sold. The products of this business can be sold through SMEs, nearby stalls / shops, or online so that their reach is even wider. Developing the agricultural sector, by providing modern technology facilities / assistance and superior seeds / fertilizers as well as bactericidal assistance so that it can produce fast and good harvests for rural communities. The community farming movement needs to be encouraged, where people can use their house yards or their fields to be planted with vegetables or fruit plants that can be used as food investment for some time to come, people can plant any food plants and hope that they can exchange crops as an effort to build mutual welfare. Developing the fisheries sector.

Village communities can be taught to cultivate fish, which later can be consumed by themselves or sold and become a source of income. The house yard or empty land can be an opportunity to build a fish pond, of course, it requires direct training or through a fish cultivation guide book. Managing the marketing sector, the community can be trained to use technology for selling and promotion via online media so that marketing is more widespread, transportation access also needs to be facilitated in the village so that distribution runs smoothly so that the economy runs smoothly and increases. The four strategies above must be adapted to the potential and the community environment. Selected people are needed to be included in a multidisciplinary team of facilitators who are able to guard the community from the start until the community is able to independently. For this reason, building public awareness to advance needs to be done beforehand. Therefore, it is necessary to cooperate with various parties to realize the goals of village development and good public services. 


\section{Reference}

[1] Kuncoro, Mudrajad, 2003, Ekonomi Pembangunan : Teori, Masalah, dan Kebijakan, UPP AMP YKPN, Yogyakarta.

[2] Pranarka, Vidyandika, 1996. Pemberdayaan, Rineka Cipta, Jakarta.

[3] Payne, Malcolm, 1997, Modern Social Work Theory, MacMillan Press Ltd, London.

[4] Rukminto, Adi Isbandi, 2002. Pemikiran-Pemikiran dalam Pembangunan Kesejahteraan Sosial, LPFE UI, Jakarta.

[5] Sugiarto, Edi. 2005. Membangun Masyarakat Memberdayakan Rakayat Kajian Strategis Pembangunan Kesejahteraan Sosial Dan Pekerja Sosial. Bandung: PT Ravika Adimatama.

[6] Sensing,Tim.2011. Qualitative Research: A Multi-Methods Approach to Projects for Doctor of Ministry Theses. Wipf and Stock Publishers.

[7] Soerjono, Soekanto. 2002, Sosiologi : Suatu Pengantar, PT. Raja Grafindo Persada, Jakarta. 